\title{
IMPACT OF PROMOTION ON PROFITABILITY OF AN ORGANISATION: A STUDY OF NIGERIAN BOTTLING COMPANY PLC
}

\author{
ULOKO Anthonia*
}

*Corresponding Author: -

\begin{abstract}
: -
The study assesses the impact of promotion on the profitability of the Nigeria Bottling Company Plc, Enugu Plant. The population of the study was made up of 56 management staff drawn from marketing, sales, and accounting/finance departments of the company. Employing a census technique, the whole population of 56 management staff constituted the sample size of the study and data obtained from the 56 copies of the questionnaire were presented using descriptive statistics whereas, multiple regression analysis with the aid of the Statistical Package for Social Science (SPSS) was conducted to test both the company's financial statement from the year 2003 to 2012 and the hypotheses. The findings from data analysis of company's financial statement shows that, profit is slightly influenced by the variables of sales income not necessary cost of promotion, while the results of the hypotheses testing indicated that, advertising has no significant impact on profitability; sales promotion has a significant impact on profitability; personal selling has no significant impact on profitability; public relations has a significant impact on profitability. The need for an organization to properly coordinate its promotional strategies to achieve a clear consistent and competitive message about itself and its products has become an issue of concern to every result driving firm. The study concluded that, promotion is an important tool that helps companies to improve their profitability. We recommended that there is the need for organizations to increasingly integrate effective promotion in their activities to improve their profitability and competitive advantage.
\end{abstract}

Keywords: Promotion, Profitability, Organization, Bottling, Company, Nigeria 


\subsection{INTRODUCTION}

\section{Background to the Study}

Promotion is an integral part of our social and economic systems. In our complex society, promotion has evolved into a vital communications system for both consumers and businesses. The ability of promotion methods to deliver carefully prepared messages to target audiences has given the marketers a major role in the marketing programs of most organizations (Belch and Belch, 2009). The authors further stated that, companies ranging from large multinational corporations to small businesses increasingly rely on promotion to help them (companies) market their products and services which in turn increases their profitability. In market-based economies, consumers have learned to rely on promotion for information they can use in making purchase decisions (Belch and Belch, 2009).

Firms use promotion to reach, inform and persuade the existing and potential customers to buy the needed satisfying product for resale or ultimate consumption. Promotion focuses on preparing the organizational messages effectively, as effectively designed messages influence the behaviors of consumers, which result in improved sales and profit. Promotion mix works as a bridge between the seller and customer. The seller uses different promotional tools for reaching the target market, depending on the nature of the product and mental filter of the target audience. It also helps the seller to have a two-way discourse with the consumer at pre- selling, selling, consumption and post purchase stages of the product.

Effectively employed promotional tools for a product influence the buying and consumption patterns of the customers and provide maximum return on investment to seller. However, one of the great challenges to a firm in the modern competitive environment is to make customers brandloyal, and to retain them for its survival and profitability, and this retention is based on the product features, not the price and place, and promotional activities.

Promotion's expenditure in India, different marketing companies are projected to be Rs 5,000 crores and focus on activities of sales promotion by the industry of Indian has increased by the figure of 500 to 600 percent during the last 3 to 5 years (Economic Times, June 15, 2003). In year 2001, there were as many as 2,050 schemes of promotion that amounted to Rs 80,000 crore in the Fast-Moving Consumer Goods (FMCG) Industry (Rizvi \& Malik 2011) cited (Dang, Koshy, \& Sharma, 2005).

In Nigeria, promotion started with the multinational trading companies like UTC, Leventis and Kingsway. It was until the late 1980s that promotion took a very dramatic turn in Nigeria marketing environment. It becomes increasingly used by many organizations in order to compete effectively with their competitors in the market. It is obvious that evidence show that organizations, private and public, local or international, small or big, and the traditional local medicine dealers and practitioners are not left out in promotion because of the services they render to the public (Abdullahi, 2012) .

The total promotion campaign expenditures spent in Nigeria each year is approximately Twenty-one billion naira (N21, 000,000,000) (Aren, 2009). According to the report of Aren (2009) on 'Contemporary Advertising' where 35 percent $(35 \%)$ of this capital expenditure goes on Television commercials, 20 percent $(20 \%)$ on Radio campaigns, 15 percent $(15 \%)$ on Billboard advert, 8 percent (8\%)on Press advert, 12 percent (12\%)on shows, 5 percent (5\%)on below the belt like Posters and Hand bills, while the remaining 5 percent $(5 \%)$ is on Point of Sales adverts. Large multinationals and indigenous companies like MTN, Celtel, Glo, Coca-Cola, Pepsi, Nokia, Motorola,

Procter \& Gamble, Cadbury, Liver-brothers, Unilever, Nestle, Guinness (etc) budget as much as almost 10-30 percent (10\%-30\%) of their entire budget on promotion campaign each year (Aren, 2009). In a similar vein, Awe, Sholotan \& Asaolu (2010) observed that, the Nigerian Fast Moving Consumer Goods (FMCG) sector involves manufacturing and marketing of soaps, detergents, home and personal care products, and electrical goods, as well as food and nutritional products. This sector comprises of four major companies - PZ, Unilever, Procter, and Gamble (P\&G) and Reckitt Benckiser (RB).

\section{Statement of Research Problem}

The advent of Industrial Revolution has led to the introduction of modern machines in the production sector to boost the production of goods and services. This revolution brought about large amount of goods and services available for sales. In this regard, consumers are exposed to varieties of products and are required to select which of the products, from which company will give them optimum satisfaction they desire (Blattberg, Briesch and Fox, 1995).

In the light of the foregoing, for a company to surpass her competitors in a highly competitive market, it has to improve and prove some certain level of marketing competences to gain the attention and interest of the consumers. (Kotler and Armstrong, 2006). Consequently, effective promotion usually yields positive results: that impact on profit ratio; hence the product that gets to the final consumer must satisfy his or her want (Kotler and Armstrong, 2006). Nigerian Bottling Company Plc has been using a lot and different promotional strategies to increase sales in recent times. Amongst these are Under the Crown, Premium, Scratch and Win, Free Gift. Also, some incentives range from Cash, T-Shirts, FaceCaps, Bags, Openers, Biros, Free drinks, Television, Radio etc. to attract more sales (NBC Plc 2012). Despites all these efforts placed by Nigerian Bottling Company Plc on its promotional activities which costs the organization millions of naira in recent time, the organization still experiences low profit. For example, profit margin dropped from N87,698,438 
in 2005 to N77,609,237 in 2006, it further dropped from N77,609,237 in 2006 to N68,529,128 in 2007 and it dropped from N68,529,128 in 2007 to N59,674,516 in 2008. The situation was more alarming in 2009, where the dwindling profit margin moves from N59, 674,516 in 2008 to N47, 553,874 in 2009. Based on the facts and figures presented above, it becomes worrisome why despite all the promotional activities of Nigerian Bottling Company Plc, the prospect of profit keeps dropping abysmally (NBC Plc 2012). It is against this backdrop that the researcher is conducting research to determine the impact of promotion on the profitability of an organization with Nigeria Bottling Company Plc Enugu Plant in focus.

\section{Objective of the Study}

The main objective of this study is to determine the impact of promotion on the profitability of an organization. The specific objectives focus on determining the impact of each of the variables of promotion on profitability of Nigeria Bottling Company Plc, which include the following:

i) To assess the impact of advertising on profitability of Nigeria Bottling Company Plc.

ii) To determine the impact of sales promotion on profitability of Nigeria Bottling Company Plc.

iii) To determine the impact of personal selling on profitability of Nigeria Bottling Company Plc.

iv) To evaluate the impact of public relation on profitability of Nigeria Bottling Company Plc.

\subsection{Literature Review}

\section{Conceptual Clarifications Promotion}

The concept of promotion is regarded as having the same meaning in most of the literature on the subject; Shimp (2003) makes a distinction between these concepts. He describes promotion as the aspect of general marketing that promotion management explicitly deals with. Promotion, on the other hand, is a "more encompassing term" that includes communications via any or all of the marketing mix elements. Promotion represents the collection of all elements in an organization's marketing mix that "facilitate exchanges by establishing shared meaning with the organization's customers or clients" (Makale, 2004).

Promotion in marketing is aimed at creating an awareness of the organization and its product(s) and/or service(s) in order to increase sales and make a profit. The sender (organization) conveys messages about the organization's product(s) and/or service(s) to the receiver (customer) in order to persuade the customer to buy the organization's product(s) or to make use of its service(s). In order to create a lasting relationship, messages focus on the brand, customers' needs and the organization's commitment to society. A brand is the sum of all emotions, thoughts and recognitions that people in the target audience have about an organization (McNamara, 2001).

Promotion is well-suited to accomplishing various marketing objectives, such as stimulating sale force enthusiasm, invigorating sales for a mature brand, facilitating the introduction of new products, increasing on- and off-shelf merchandising space, encouraging repeat purchases, and reinforcing advertising (Shimp, 2001). Promotion is an exercise that performs the roles of information, persuasion and influence to purchase certain goods and services (Kotler, 2003). Promotion is an approach used to adjust international market or local market (Kotler, 2004). Promotion has been defined as the coordination of all sellers initiated efforts to setup channels of information and persuasion in order to sell goods and services and to promote an idea (Belch \& Belch, 2007). Promotion consists of all activities intended to make a company communicate with its present and potential customers (Alabar, 2007).

\section{Profitability of an organization}

Profitability of an Organization refers to a comparison between the profits made from the business with the capital assets of a business. The capital assets include things such as the value of the company's building, plant and machinery etc. Profitability is expressed in terms of the rate of return of these capital assets (Wise-GEEK, 2003). Profitability is a business term that is used to mean the likelihood of a business venture earning the desired level of income and incentives, within a specific period of time, under certain prevailing business conditions (Sweney, 2004).

In economics, profitability is the difference between the price and the long run average cost. The difference is equal to zero in the case of a perfectly competitive market or in the case of monopolistic competitive, but it is different from zero in an oligopolistic or in a monopolist market. In addition, in the short run, profitability is obtained by considering the short run cost curves and this could allow the existence of profitability also in a monopolistic competitive market (Luca, 1999).

\section{Theoretical Framework: Theories of Promotional Elements (Mix) Theories of advertising}

In this literature review, we identified four distinct alternative theoretical formulations of' how advertising produces its effect. Chandy, Rajesh, Gerard, Tellis, Maclnnis, \& Thaivanich (2001) summarize these four theories. 
Pressure -response theories of advertising assume that advertising effects are a function of the advertising dollars spent or messages received. It also assumes that stable relations exist between advertising pressure and advertising effect. This theory tends to ignore the quality of advertising creative work in causing advertising effects.

Active learning theories of advertising assume that advertising conveys information that leads to attitude change and, in turn, to changes in marketplace behaviour.

Low involvement theories of advertising assume, at least in some Advertising situations, that the information content of advertising is not of importance to the consumer and that it tends to be passively stored rather than actively evaluated in relation to consumer reactions to products and services. In this conception, advertising effects cumulatively increase brand relevance or salience, result in changed purchase behaviour, and lead to revised attitudes only after the brand has been purchased or used.

Dissonance reduction theories suggest that behaviour may lead to attitude change and that newly formed attitudes are reinforced and stabilized by information from advertising. This review of theories in advertising suggests that there is no consensus about how consumers interact with advertising or how these specific interactions do not lead to particular results in the marketplace.

All theories, except Pressure-Response theory, involve three elements: Learning, attitude change and behaviour change. The difference is only with regard to the sequence of these elements and therefore three theories follow three different sequences.

- Learning - attitude change - behaviour change (Active learning theory)

- Learning - behaviour change - attitude change (Low involvement theory)

- Behaviour change - attitude change - learning (Dissonance reduction) Chandy, Rajesh, Gerard, Tellis, Maclnnis, \& Thaivanich (2001).

\section{Theories of sales promotion}

Sales promotion is giving the customer something extra, rewarding them for their behavior on this particular purchasing occasion. There are several theories which support the concept of reward as a motivator including Belch \& Belch (2009). The conditions of sales promotion are classical and operant conditioning. Whereas classical conditioning is largely associated with advertising operant conditioning is seen as an explanation for consumer behaviour in relation to sales promotion. Operant conditioning suggests that the response of the individual is likely to be affected by positive reinforcement (reward) or negative reinforcement (punishment), although the effect is likely to cease when these reinforcements are taken away. Edward Thorndike suggested that the 'law of effect', which had to do with positive and negative consequences of actions, is also relevant to sales promotion. The law states that the consequences of behavior now will govern the consequences of that behavior in the future. In other words once a buying pattern is achieved it will continue into the future. John Watson, US psychologist and founding father of American behaviouralism, introduced the concept of shaping, chaining, and priming (Tahir, 2007).

\section{Theoretical Model Guiding the Study}

Promotional variables and model are as follows

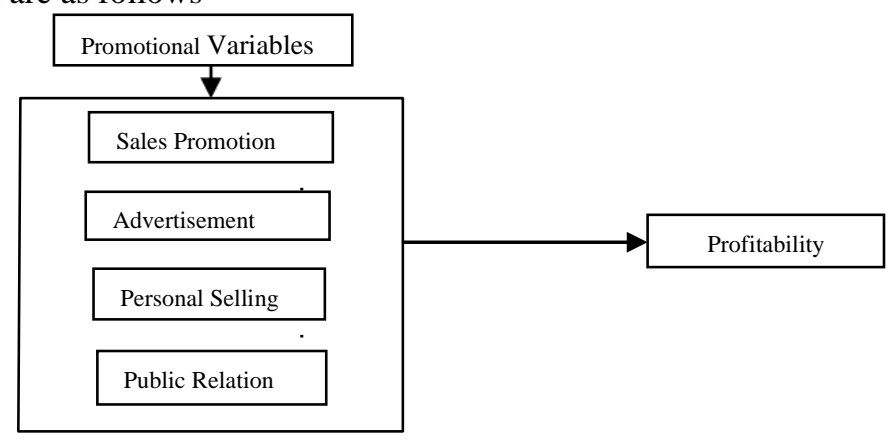

Source: Research desk (2014)

\subsection{Theoretical Mode}

The above model explained the promotional activities and their influence on profitability.

1. Sales promotion is a communication activity that provides extra value or incentives to ultimate consumers, wholesalers, retailers thereby enhancing the profitability of the organization.

2. Advertising is the ability of the organization to perform the spreading of information by marketer relating to a product, service or ideas through different medium accurately and effectively that will lead to profitability.

3. Personal selling is the ability of organization's personnel to adequately communicate to present and potential buyers through face-to-face contact or through the use of advance technology via telephone, video conferencing etc to enhance the profitability rate of the organization.

4. Public relation is the capacity of firms to communicate positive image of their organization and its product and 
services via the use of tools like news release, which will highly increase the profit margin of the organization.

Thus, the combination of these four dimensions or variables will determine the overall promotional activities that enhance the profitability of an organization. However, where these variables are absent the organization may end up operating at a loss (Kitchen, Brignell and Jones, 2004).

\section{The Determinant of a Company's Profitability}

According to Hunt (2002), the followings are the determinant of a company's profitability

\section{Sales}

Sales are an important factor in determining profitability. The return on sales ratio measures profits after taxes based upon the current year's sales. If sales numbers are high, a company is better prepared to handle adverse market conditions and economic downtrends. The gross profit margin is a measure of gross profit earned on sales. An effective sales strategy is essential in increasing a company's profitability.

\section{Pricing}

Price setting is a key factor in determining profit. Careful analysis is necessary in determining the correct pricing strategy for a company. A business owner must look at what competitors are charging and determine what prices he should charge to maximize profits. An important factor to consider in pricing strategy is determining what price customers are willing to pay for a product. Customers will pay more for niche products or services that are not readily available elsewhere. A business owner does not want to leave money on the table by undercutting the price charged for products and services.

\section{Expenses}

For a company to become profitable, income must exceed expenses. Expenses can be defined as the cost of resources used in the activities of a business. Profits for the company are determined by analyzing what is left over after expenses are subtracted from total revenue. Any cost-saving measures initiated by a company will bring expenses down and increase overall profitability.

\section{Measuring Profitability}

Measuring profitability is the same as measuring the success of a business. An income statement shows a breakdown of income and expenses during the business year. One measure of a company's profitability is the profitability ratio. Profitability ratios analyze the financial health of a business. A profitability ratio looks at how profit was earned in relation to sales, total assets and net worth. There are two types of profit margin we can calculate for a business - gross and net (Hunt, 2002).

\section{Gross profit margin}

The gross profit margin is the percentage of sales left after we subtract the production cost of goods sold from the total salesfigure. It measures the percentage of sales naira remaining to pay the overhead expenses and provide us with a profit.

The gross profit for a manufacturing business is the difference between the value of goods sold to clients (sales) and the cost of direct materials, direct labour and factory overheads incurred in making these goods (cost of goods).

\section{Net profit margin}

The net profit margin shows how much money is left after deducting direct and overhead expenses from gross profit. This ratio is the percentage of sales naira left after subtracting the cost of sales and all other expenses, except tax.

This information will help to compare the business's return on sales with the performance of other businesses in the industry. Using the above example, if the overheads were N140,000:

\section{Empirical Review \\ Impact of promotion on the profitability of an organization}

Some authors believe that the impact of promotion on organization effectiveness is minimal and non significant (Boddewyn and Leardi, 1989; Dekimpe, Hanssens and Silva- Risso, 1999; Srinivasan, Srini \& Anderson, 2000; Pauwels, Hanssens \& Siddarth, 2002), others like Odunlami and Ogunsiji (2011) believe that the effect is high and significant.

Some of the recent studies include Pauwels et al. (2002) which examined the permanent effect of sales promotion on accumulative annual sales for the two products categories which include storable and perishable products. Their findings show that perishable and storable product categories lack permanent effects on sales promotion. Furthermore it is revealed that effects of sales promotion are short lived and persist 
only on average of two (2) weeks and at most eight weeks for both product categories. The research's results prove the common concept that sales promotion makes only benefits which are temporary for the established brands.

The result of Dekimpe et al. (1999) also shows that, there are rarely any permanent effects of sales promotions on the volume of sales. Their findings proved that sales promotion does not change the structure of sales over the long run. They suggest that the diminishing impact of sales promotion may be because of choice of brand and quantity which is purchase and category incidence such as energy crisis.

Pauwels et al. (2002) are of the opinion that when a consumer is exposed to a sales promotion offer majority of the time, the consumer has already purchased and practiced a particular brand so the impact of learning that purchase is minimal and is easily balanced by a simultaneous and similar competitive offering. Therefore the immediate effects of sales promotion are small, because of price promotion, consumers are forced to make purchases but this impact on sales cannot only be explained by accelerated rate of purchase due to price reductions.

\section{The Impact of Advertising on the Profitability of an Organization}

In Chandy, Rajesh, Gerard, Tellis, Maclnnis \& Thaivanich (2001), it is found that the impact of advertising on sales and profit varies across markets channels and according to creative aspects or advertising appeals. Similar issues as the ones dealt with in the studying of Tellis, Chandy \& Thaivanich (2000) were addressed. They categorize the appeals as argument based (cognitive) or emotional. They find that argument based on advertising is more effective for new product. On the other hand, emotional based advertising is more effective in mature product. Kokemuller (2012) stated that, advertising can have both immediate and long-term effects on the industry's sales volume and profitability ratio, depending on the objectives. Short- term sales promotions tend to lead to higher sales volume more quickly, whereas long- term brand management advertising produces higher sales and profits over time.

The economic impact of advertising on the sales volume and profitability is that, it makes proper identification of individual brand known and their advertisements easier while the brands advertised are easily recognized at the point of purchase. This has helped to build brand preference for product all over Nigeria and the world at large. As generally known that reputation connotes emphasis, the more the products and service are being advertised especially during sport sponsorship, educational events and many social functions, the more the advert is registered in the brains of the consumers. Even someone who does not always watch TV but due to the love the person has for sport, he has no choice but to see such adverts, hence advert can change the orientation of such consumer, influence his buying behaviour and increase his taste for such product above all other branches (Adekoya, 2011) cited (Jefkins, 1990).

\section{The Impact of Sales Promotion on the Profitability of an Organization}

The impacts that sales promotions have on the profit of an organization are:

1. Encouraging purchase of large size unit. Sales Promotion consists of diverse collection of incentive tools, both long and short term designed to stimulate quicker or greater purchase of products or service by consumer, for example, the use of premiums, product warranties etc. stimulate consumer purchase in larger quantities (Rotimosho, 2003).

2 Generating trials among non-users. Trials among non-users of a product are generated through invitation of prospective purchasers to try the product without cost or little cost with the hope that they will buy the product. Persuading retailers to carry new items and higher level of inventory. Sales Promotion encourages retailers to give shelf space to new products. Manufacturers provide retailers with financial incentives to stock new products.

3. Encouraging off season buying. Sales Promotion has also encouraged off season buying especially during the festive periods, people tend to buy more of a particular product because of the added value, compared to normal season.

4. Building brand loyalty. Sales Promotion helps to build brand loyalty by giving the seller the opportunity to attract a loyal and profitable set of customers which provides sellers some protections from competition and greater control in planning their marketing mix (Shira, 2003).

Conclusively, sales promotion has been seen as focusing on customer relationship management, free gifts, free sample, price discount, etc. If an organization effectively implements promotional techniques, it will not only encourage large purchase but it will also increase the sales performance of an organization, invariably leading to the achievement of the stated objectives (Odunlami \& Ogunsiji, 2011).

\section{The Impact of Personal Selling on the Profitability of an Organization}

The study of Mehir, Bipasha and Kamal (2008) aimed at Assessing Productivity of Personal Selling Effort in India: An Econometric Approach. In their study, it was revealed that the personal selling effort has significant positive effect on adjusted sales and this effect varies from one brand to another using multiple regression analysis with ordinary least squares (OLS) algorithm. Coming to the productivity of personal selling effort, it has been observed that the sales personnel of brand B are more efficient than brand A. This study ignores completely the interaction between personal selling effort and other efforts in marketing mix, due to small number of observations. It does not include those factors, which influence the productivity of sales personnel since data were not available with both the firms.

\section{The Impact of Public Relation on Profitability of an Organization}

Public relations can help create a unified message that helps marketing and business development. This can help define 
product or service from the customer's point-of- view, get you on the speaker's panel at trade shows and conventions, get articles about your firm in the relevant trade publications, and help with collateral material development. Events as a publicity tool have been used as an integral part of the PR business for years and can be far more effective than bombarding editors with press releases. Many companies focus on staging events mainly because their products get lost trying to get undeserved publicity. Events, on the other hand, create great photo opportunities if timely and of interest to the community. Enthusiasm and persistence are critical assets when it comes to communicating your message to the public. When it comes to working with firms, Webster suggests, "It is essential that clients don't bluff about their knowledge, and therefore their expectations of the PR process. The PR firm can't help unless you adequately communicate the scope of your knowledge about the business.” Good PR work, including press coverage, goodwill generated, and increased impact on public perception of the firm can be powerfully effective. According to media experts, articles are believed and remembered four to six times more than advertising Stanton, Etzel \& Walker (2001) and Alabar (2007).

Mahmud, Almahirah, Said, and Freihat (2014) aimed at determining the effect of promotion mix practiced by Jordanian shareholding Ceramic and glass production companies on consumers purchasing decision. They explored multiple regression analysis models and reported that, there is no statistically significant effect of the following combined promotional activities: (advertising, personal selling, sales promotion, publicity, and public relations) carried out by Jordanian shareholding Ceramic and glass production companies on consumers purchasing decision. There is a statistically significant effect of the following promotional elements: advertising, Personal Selling, and sales promotion practiced by Jordanian shareholding Ceramic and glass production companies on consumers purchasing decision. There is no statistically significant effect of the Publicity, and public relations practiced by Jordanian shareholding Ceramic and glass production companies on consumers purchasing decision.

\section{Impact of Promotion on Profitability of Organizations in Nigeria}

Promotion is a key ingredient in marketing campaigns, as the need to promote a product, service or an idea cannot be over emphasized (Obi, 2002). Obi (2002) opined that promotion consists of related activities that are necessary to supplement sales promotion and personal selling. According to the author, some of these include, distribution of sample products to customers, exhibitions, or demonstration of products at stores or trade fairs or shows and preparation of printed materials used by sales people or for point-of sale displays. A combination of the above variables defines a firm's promotional programme that hopes to influence consumers to patronize and become loyal to the organizations offering which as a result increases profitability (Banabo and Koroy, 2011).

Promotion improves organization effectiveness through increase in profitability from higher sales (Okoli, 2011). The author explains that the "essence of setting up a business organization is to make profit and without profit, a business is bound to fail". Loudon and Bitta (2002) said that promotion plays a significant effect on decisions which help in achieving theorganizational objectives and increase it profit.

Ozor (2000) declared that producers of goods and services are presently aware that promotion does not only inform and persuade, but can strive towards profit making through increased sales. It has been established in literature that only consumers with repeat purchases are profitable (Nagar, 2009).

\subsection{Research Methodology \\ Research Design}

This study employed survey design method through which data were collected and analyzed to obtain the results. Due to the nature of the study, the researcher adopted triangulation method where both secondary and primary data were analyzed and results integrated.

The techniques allow the researcher to describe what promotional tools are, how they are used, where and their impacts. In addition to this, the study also described common characteristics among the study population of the research. The opinions of management staff of Nigerian Bottling Company Plc products as respondent were sampled through structured questionnaire. The population for this study includes all management staff of Marketing, Sales and Accounting/Finance departments of Nigerian Bottling Company Plc Enugu State Plant. This comprises a total of 56 management staff of NBC Plc. This research deals more directly with the management staff because it is focused on profitability of the organization, thus giving the researcher the needed and accurate data for effective appraisal.

The census sampling technique was employed to determine the respondents for data analysis. The sample population for this study comprises all management staff of Marketing, Sales and Accounting/Finance departments of the East, South-East and North-Central (Enugu Plant, Ogoja Depot, Ida Depot and Makurdi Depot) under Nigerian Bottling Company Plc Enugu State Plant. As such, sample sizes of 56 respondents were determined using the census technique in which all elements of the target population were used as a sample. This can be found in Israel (2013) that small population attracts a census technique. This is meant to support the results of the secondary data analysis.

The main source of data for this study is secondary data. Primary data was used however to support that of the secondary data. The secondary data that was used for this research essentially relates to company's profit (PF), Sales 
Income (SI) and Cost of Promotion (CP). The secondary data was obtained for the period of 10 years. Other secondary sources of the data were obtained from textbooks, journals, internet, articles, magazines and newspapers.

Primary data essentially cover qualitative data on advertising (ADV), sales promotion (SPR), personal selling (PES) and public relation activities (PRA) of the company. The method of primary data collection was the use of questionnaire approach. The questionnaire was designed to cover respondents with prior knowledge of Nigerian Bottling Company Plc.

In this work, the researcher made use of questionnaire instruments and profit \& loss account. The Questionnaire was designed to collect information from all management staff of Marketing, Sales and Accounting/Finance department of Nigeria Bottling Company Plc Enugu Plant. The questions were formulated so as to elicit information on the Impact of Promotion on Profitability of Nigeria Bottling Company Plc. Five Likert-scales questions, which range from strongly agree to strongly disagree were used (strongly agree $=5$, agree $=4$, undecided $=3$, disagree $=2$, strongly disagree $=1$ ) These were used to reflect the agreement of respondents on the statements posed to them in the questionnaire.

In this study, the two most common types of validity, which are content and construct validity, were considered. While content validity was tested through the expert contributions, construct validity was tested with the use of Factor analytical tool that considered Kaiser-Meyer-Olkin (KMO) and Bartlett's Test of Sphericity. The result of the validity test indicates that the instrument for the data collection is valid, while Cronbach Alpha coefficient showed a reliability of 0.86 which is considered reliable for the study.

\section{For the Secondary data Estimation, the following procedure is followed Panel unit root test}

Panel unit root test was done to determine if the data is stationary or not. If stationary, co- integration test will be used for the analysis, if not, ordinary least regression will be done. Maddala and Wu (1999) propose a panel unit root test developed from Fisher (1932). The test essentially combines the p-values of the test statistic for a unit root in each residual cross-sectional unit. The test is non- parametric and maybe computed for any arbitrary choice of a test for the unit root. The test has a Chi-square distribution with $2 N$ (where $\mathrm{N}$ is the cross section) degrees of freedom. Using the additive property of the chi-squared variable, the following test statistic can be derived:

$$
\lambda=-2 \sum_{\mathrm{i}=1}^{\mathrm{N}} \log _{\mathrm{e}} \pi_{\mathrm{i}}
$$

Here, $\pi_{\mathrm{i}}$ is the $\mathrm{p}$-value of the test statistic in unit i. An important advantage of this test (tool) is that it can be used regardless of whether the null is one of integration or stationarity.

\section{Model Specification.}

To take into account the contributions of each of the plant and depots (Enugu plant, Ogoja depot, Idah depot and Makurdi depot) to the profitability of the company, a fixed effect model specification was done which took into account the individuality of the company's uniqueness and contribution.

The fixed effect model specification takes the form of the relationship below

Yit $=$ Profit $(\mathrm{PF})$

$$
\text { Yit }=\beta 1 i+\beta 2 X 2 i t+\beta 3 X 3 i t+U i t
$$

$\mathrm{X} 2 \mathrm{it}=$ Sales Income (SI)

$\mathrm{X} 3 \mathrm{it}=$ Cost of Promotion $(\mathrm{CP})$

Uit $=$ Stochastic Term

$\beta 1 \mathrm{i}=$ Regression coefficients

Equation (1) is known as the fixed effect (regression) model (FEM) or least-squares dummy variable (LSDV) model. The term "fixed effect" is due to the fact that, although the intercept may differ across individual plant and depot, each individual's intercept does not vary over time. This was done by the use of differential intercept dummies.

Where

$$
\mathrm{Yit}=\alpha 1+\alpha 2 \mathrm{D} 2 \mathrm{i}+\alpha 3 \mathrm{D} 3 \mathrm{i}+\alpha 4 \mathrm{D} 4 \mathrm{i}+\beta 2 \mathrm{X} 2 \mathrm{it}+\beta 3 \mathrm{X} 3 \mathrm{it}+\mathrm{Uit}
$$

D2i=Dummy Variable for Enugu plant D3i= Dummy Variable for Ogoja depot D4i= Dummy Variable for Idah depot Yit $=$ Profit $(\mathrm{PF})$

$\mathrm{X} 2 \mathrm{it}=$ Sales Income (SI)

$\mathrm{X} 3 \mathrm{it}=$ Cost of Promotion $(\mathrm{CP})$

$\alpha_{1}=$ Represents the intercept of Makurdi Branch

$\alpha_{2}, \alpha_{3}, \alpha_{4}=$ the differential intercept coefficients, tell us how much the intercepts of Enugu plant, Ogoja depot, Idah depot differ from the intercept of Makurdi depot which is the control.

$\beta 2, \beta 3=$ Regression coefficients

Uit $=$ Stochastic Term 
However,

$D 2 i=1$ if the observation belongs to Enugu plant, 0 otherwise;

$D 3 i=1$ if the observation belongs to Ogoja depot, 0 otherwise;

$D 4 i=1$ if the observation belongs to Idah depot, 0 otherwise.

Since we have one plant and three depots, we have to use only three dummies to avoid falling into the dummy-variable trap (i.e., the situation of perfect co-linearity). Here there is no dummy for Makurdi depot.

The expected a priori expectations of the variables is given as $\beta 2>0, \beta 3<0$,

Substituting our real values we have:

$$
\mathrm{PF}=\alpha 1+\alpha 1+\alpha 2 \mathrm{D} 2 \mathrm{i}+\alpha 3 \mathrm{D} 3 \mathrm{i}+\alpha 4 \mathrm{D} 4 \mathrm{i}+\beta 2 \mathrm{SI}+\beta 3 \mathrm{CP}+\mathrm{Uit}
$$

The fourth equation investigates the relationship between profitability and primary data variables of advertising (ADV), sales promotion (SPR), personal selling (PES) and public relation activities (PRA) of the company. The relationship is modeled as follows in equation four below:

Where,

$$
\mathrm{PF}=\mathrm{f}(\mathrm{ADV}, \mathrm{SPR}, \mathrm{PES}, \mathrm{PRA})
$$

$\mathrm{ADV}=$ advertising

SPR $=$ Sales Promotion

PES = Personal Selling

PRA = Public Relation Activities

The explicit form of the model is shown below in equation five.

$$
\mathrm{PF}=\beta 0+\beta 1 \mathrm{ADV},+\beta 2 \mathrm{SPR},+\beta 3 \mathrm{PES}+\beta 4 \mathrm{PRA}+\mathrm{Uit}
$$

\section{Method of Data Analysis}

The study employed descriptive statistics such as mean, standard deviation, Skewness, kurtosis, tables, percentages, histograms and charts to present descriptive statistics. Least- squares dummy variable (LSDV) regression analysis was used to test $\mathrm{n}$ the relationship between variables of the study. The hypotheses were tested using the probability values of the estimate. The usual test of goodness-of-fit and significance was performed.

\subsection{Results and Discussion}

Panel unit root at levels

Table 1: Panel unit root at levels

\begin{tabular}{|c|c|c|c|}
\hline Variable & $\begin{array}{c}\text { Levin Lin \& Chu } \\
\text { P-value** }\end{array}$ & $\begin{array}{l}\text { ADF-Fisher chi- } \\
\text { P-value** }\end{array}$ & $\begin{array}{c}\text { square } \\
\text { P-v-Fisher } \\
\text { hi-square P-value** }\end{array}$ \\
\hline PF & 0.0012 & 0.0135 & 0.0014 \\
\hline CP & 0.0070 & 0.0000 & 0.0000 \\
\hline SI & 0.0009 & 0.0002 & 0.0001 \\
\hline
\end{tabular}

Source: Researcher's Computation (2014), SPSS Version 20.0

The study made use of three panel unit root processes: Levin Lin \& Chu Test examined the common unit root process while ADF- Fisher Chi-Square and Phillips Peron Fisher Chi Square examined the individual unit root processes. The p-values of all the unit root processes at levels are less than the critical value of 0.05 . This shows that the variables are stationary at levels at $p<0.05$ for both the common and individual unit root. With the unit roots stationary at levels, Ordinary Least Squares (OLS) can be used to estimate the relationships that exits among the variables of the model.

Table 2: Impact of branch promotion on profitability

\begin{tabular}{|c|c|c|}
\hline Plant/Depot & $\begin{array}{c}\text { Computation } \\
\boldsymbol{\alpha 1}+(\boldsymbol{\alpha} \mathbf{2} \boldsymbol{\alpha 3} \boldsymbol{\alpha 4})\end{array}$ & $\begin{array}{c}\text { \% Contribution to } \\
\text { profitability }\end{array}$ \\
\hline Enugu Plant & $5.7962+0.416$ & 6.2122 \\
\hline Ogoja Depot & $5.7962-0.418$ & 5.3782 \\
\hline Idah Depot & $5.7962+0.355$ & 6.1512 \\
\hline
\end{tabular}

Source: Researcher's Computation (2014), SPSS Version 20.0

As shown in table 2 above from the estimation, Enugu Plant's overall contribution to the company's profitability was the highest (6.2122), followed by that of Idah depot (6.1512) and lastly Ogoja depot (5.3782). However, Enugu Plant and Ogoja depot are statistically significant $(p<0.05)$ whereas Idah depot is not statistically significant $(p>0.05)$. The 
differences in the intercepts as shown in table 3 below may be due to unique features of each of the plant/depot, such as differences in management style or managerial talent of the managers. This result shows that the intercept of Enugu Plant and Idah Depot differ from that of the comparison Company Makurdi Depot represented by $\alpha 1$.

Table 3: Fixed effect least square dummy variable regression analysis of branch effect on profit Coefficients $^{\text {a }}$

a. Dependent Variable: PF

\begin{tabular}{|c|c|c|c|c|c|c|}
\hline \multirow{2}{*}{\multicolumn{2}{|c|}{ Model }} & \multicolumn{2}{|c|}{$\begin{array}{l}\text { Unstandardized } \\
\text { Coefficients }\end{array}$} & \multirow{2}{*}{\begin{tabular}{|c|}
$\begin{array}{c}\text { Standardized } \\
\text { Coefficients }\end{array}$ \\
Beta
\end{tabular}} & \multirow[t]{2}{*}{$\mathrm{T}$} & \multirow[t]{2}{*}{ Sig. } \\
\hline & & $B$ & $\begin{array}{l}\text { Std. } \\
\text { Error }\end{array}$ & & & \\
\hline \multirow{6}{*}{1} & (Constant) & 5.796 & 51.992 & & 1.394 & .236 \\
\hline & SI & .275 & .131 & .895 & 2.092 & .010 \\
\hline & $\mathrm{CP}$ & -.002 & .010 & -.009 & -.183 & .864 \\
\hline & D2i & 17.058 & 5.010 & .416 & .033 & .035 \\
\hline & D3i & 11.783 & 4.224 & -.418 & -1.308 & .261 \\
\hline & D4i & 14.248 & 2.805 & .355 & .951 & .040 \\
\hline
\end{tabular}

Source: Researcher's Computation (2014), SPSS Version 20.0

$$
\begin{aligned}
& \mathrm{Y}_{\text {it }}=\alpha_{1}+\alpha_{2} \mathrm{D}_{2 \mathrm{i}}+\alpha_{3} \mathrm{D}_{3 \mathrm{i}}+\alpha_{4} \mathrm{D}_{4 \mathrm{i}}+\beta_{2} \mathrm{X}_{2 \mathrm{it}}+\beta_{3} \mathrm{X}_{3 \mathrm{it}}+\mathrm{U}_{\mathrm{it} .} . \\
& \mathrm{PF}=5.796+0.416 \mathrm{D}_{2 \mathrm{i}}-0.418 \mathrm{D}_{3 \mathrm{i}}+0.355 \mathrm{D}_{4 \mathrm{i}}+0.895 \mathrm{SI}-0.009 \mathrm{CP} \\
& S \text { (bi) [0.5010] [0.4224] [2.805] [0.131] [0.010] }
\end{aligned}
$$

As shown by the regression model above, there is a positive relationship between Sales Income (SI) and Company Profit (PF) and the relationship is statistically significant $(p<0.05)$. This positive relationship of SI with PF indicates that the relationship is in line with a priori expectation. This also means that a unit increase in SI will result to a corresponding increase in PF by $89.5 \%$.

A negative relationship exists between Cost of Promotion (CP) and Company Profit (PF) and it is not statistical $(p>0.05)$ and also in line with a priori expectation. This also means that a unit increase in Cost of Promotion (CP) will cause a corresponding decrease in profit (PF) by $0.90 \%$.All the deferential dummies are positively related to profitability.

\section{Primary Data Analysis}

Testing the Hypotheses Using the Second Regression Model

Where

$$
\mathrm{PF}=\beta 0+\beta 1 \mathrm{ADV},+\beta 2 \mathrm{SPR},+\beta 3 \mathrm{PES}+\beta 4 \mathrm{PRA}+\mathrm{Uit}----(3)
$$

$\mathrm{ADV}=$ Advertising

SPR $=$ Sales Promotion

\begin{tabular}{|c|c|c|c|c|c|c|}
\hline \multirow{2}{*}{\multicolumn{2}{|c|}{ Model }} & \multicolumn{2}{|c|}{$\begin{array}{l}\text { Unstandardized } \\
\text { Coefficients }\end{array}$} & \begin{tabular}{|c|} 
Standardized \\
Coefficients
\end{tabular} & \multirow[t]{2}{*}{$t$} & \multirow[t]{2}{*}{ Sig. } \\
\hline & & $B$ & Std. Error & Beta & & \\
\hline \multirow{5}{*}{1} & (Constant) & 29.669 & 27.910 & & 1.063 & .336 \\
\hline & ADV & -.688 & .888 & -.884 & -1.772 & .137 \\
\hline & SPR & .136 & .246 & .723 & 1.650 & .016 \\
\hline & PES & .033 & .668 & .328 & -.903 & .041 \\
\hline & PRA & .219 & .035 & .163 & .375 & .023 \\
\hline
\end{tabular}

PES $=$ Personal Selling

PRA $=$ Public Relation Activities

Table 4: Coefficients ${ }^{\mathrm{a}}$

a. Dependent Variable: PF

Source: Researcher's Computation (2014) SPSS Version 20.0

\section{Discussion of the integrated findings}

The findings from secondary data analysis showed the contributions of each plant and depot on profitability of Nigeria Bottling Company Plc. Enugu plant overall contribution to the company's profitability was the highest (6.2122) and it is statistically significant $(\mathrm{p}<0.05)$ followed by Idah depot $(6.1512)$ and lastly, the contribution made by Ogoja depot is (5.3782). However, the contribution made by Idah depot is not statistically significant $(\mathrm{p}>0.05)$ while the contributions of Enugu plant and Ogoja depot are statistically significant $(\mathrm{p}<0.05)$. The differences in the intercepts as shown in (Table 2) may be due to unique features of each of the plant and depots, such as differences in management style or managerial talent of the managers. This findings show that the intercept of Enugu plant and Idah depot differ from that of the comparison company- Makurdi depot represented by $a 1$.

From the hypotheses test using primary data analysis, Sales Promotion and Public Relation have a significant impact on profitability of Nigerian Bottling Company, while Advertising and Personal Selling has no significant impact on 
profitability of Nigerian Bottling Company. The analysis of secondary data shows that there exists a positive relationship (correlation) between Profit and Sales Income, negative relationship between Profit and Cost of Promotion, and a positive relationship also between Sales Income and Cost of Promotion.

Finally, the findings showed that, profit is slightly influenced by the variables of Sales Income and not necessary Cost of promotion.

\section{Discussion of Findings}

As stated earlier, discussion in this study focuses on the contributions of the plant and depots on profitability of the organization followed by hypotheses raised and tested through the analysis of both secondary and primary data as shown below: The differential intercept dummies, D2i, D3i, D4i shows that the contributions of Enugu plant (D2i) (6.2122) and Ogoja depot (D3i) (5.3782) are statistically significant ( $<<0.05)$ while the contribution of Idah depot (D4i) (6.1512) is not statistical ( $p>0.05$ ) in comparison to the fixed depot (Makurdi). The dissimilarity in the differential intercept's dummies can be seen in (Table 3), this means that due to unique features of each of the plant and depots, such dissimilarity could be from managerial talent or management style of the managers.

Regression model shows that, there is a positive relationship between Sales Income (SI) and company Profit (PF) and the relationship is statistically significant $(\mathrm{p}<0.05)$. This positive relationship of SI with PF indicates that the relationship is in line with a priori expectation. That is to say, increase in SI will result to a corresponding increase in PF by $89.5 \%$. A negative relationship exists between Cost of Promotion (CP) and Company Profit (PF) and it is not statistical $(\mathrm{p}>0.05)$ and also in line with priori expectation. It also means increase unit in $\mathrm{CP}$ will cause corresponding decrees in PF by $0.90 \%$.

The model summary coefficient of determination $\mathrm{R}^{2}$ for the study is 0.994 or $00.4 \%$. This indicates that $99.4 \%$ of the variations in the model can be explained by the explanatory variable of the model while $0.6 \%$ can be attributed to unexplained variation captured by the stochastic term. The difference between the Adjusted R Square and $\mathrm{R}^{2}$ (i.e. $0.994-0.986=0.08$ ) shows a negligible penalty for additional explanatory variables introduced by the researcher. The Watson statistic is 2.378. This shows that there is a minimal degree of autocorrelation in the model of the study.

The analysis from primary data is to support the secondary data in this study. Using the standard error test to test the hypothesis and the decision rule to accept or reject a hypothesis, hypothesis one which says advertising has no significant impact on profitability was accepted. That is $S(\mathrm{bi})>1 / 2 \mathrm{bi}$ which is $0.888>-0.442$. That is, we accept that the estimate b1 is not statistically significant at the $5 \%$ level of significance. This implies that advertising has no significant impact on profitability of Nigeria Bottling Company Plc. This finding agreed with the findings of Kamel, Carl, and Sunil (1999) on managing advertising and promotion for profitability in New York. Other findings from a study by Chandy, Rajesh, Gerard, Tellis, Maclnnis \& Thaivanich (2001) indicated that the impact of advertising on sales and profit varies across markets channels and according to creative aspects or advertising appeals. Similar issues as the ones dealt with in the studying of Karim, (2005) also agree with the results of my findings. The findings of the study showed that the time for advertisement, as well as, the easy language used in the communication message is very important variables in effecting consumers' purchasing decisions.

The second hypothesis stated that sales promotion has no significant impact on profitability. Using the standard error test, $S$ (bi) $<1 / 2 \mathrm{bi}$, which is $0.246<0.3615$. Thus, we reject the null hypothesis. That is, we accept that the estimate b1 is statistically significant at the $5 \%$ level of significance. This implies that Sales promotion has a significant impact on profitability of Nigeria Bottling Company Plc. This finding disagreed with the findings of Syeda, Sadia, \& Syeda, (2012) on the impact of sales promotion in Pakistani companies from two diverse industries, i.e. Beverage Industry and cosmetics Industry. Similarly, Ailawadi and Neslin (1998) following a survey of the recent empirical literature on the subject found that, with respect to the earlier contributions, there is more agreement on the positive effect of sales promotion on organization effectiveness. They established that consumer promotions motivate the consumers to purchase larger amount and consume it faster; causing an increase in sales and ultimately profitability. Also, the study by Preko (2012) supports the results of this study that sales promotion is a tool employed by the company to improve profitability. The result of this study is also in line with that of Aworemi et al (2008) which found that sales promotion (price promotion) had a negative impact on profitability of Niger State Transport Authority. The empirical result of Odunlami and Ogunsiji (2011) is in principle with the result of Aworemi et al (2008). They confirmed that sales promotion is a highly effective strategy. The findings of Bamiduro (2001) also confirmed the positive relationship between sales promotion and consumption rate of soft drink products aswell as the sales volume of the beverage industry.

The third hypothesis which says personal selling has no significant impact on profitability. Using the standard error test, $S$ (bi) $>1 / 2$ bi which is $0.668>0.1614$. Thus, we accept the null hypothesis. That is, we accept that the estimate b1 is not statistically significant at the 5\% level of significance. This implies that Personal selling has no significant impact on profitability of Nigeria Bottling Company Plc. This finding disagrees with that of Okwo and Ugwunta, (2010) on Personal Selling and Profitability of the brewery firms in Nigeria. They revealed that the effect of Personal Selling on Profitability is statistically positive and significant, and personal selling impacts profitability of the brewery firms in Nigeria. Therefore, cost of sale is a major factor to be contained with by Nigerian brewers in enhancing or boosting 
their profitability.

The forth hypothesis stated that public relation has no significant impact on profitability. Using the standard error test, $S$ (bi) $<1 / 2$ bi which is $0.035<0.0815$. Thus, we reject the null hypothesis. That is, we accept that the estimate b1 is not statistically significant at the $5 \%$ level of significance. This implies that the Company's public relation has a significant impact on profitability of Nigeria Bottling Company Plc. This finding disagreed with the findings of Mahmud, Almahirah, Said, and Freihat (2014), on the effect of public relation on profitability of Jordanian shareholding Ceramic and glass production companies on consumers purchasing decision. It was revealed in their findings that there is statistically significant effect of public relation on Jordanian shareholding Ceramic and glass production companies on consumers purchasing decision.

Given the findings from both secondary and primary data analysis, it has been found that promotion is an important tool that helps companies to increase their profitability. The failure of some of the variables of promotions such as advertising and personal selling to produce significant impact on profitability may be due to the failure of the Nigeria Bottling Company Plc to give much attention to improve on such variables during the study period.

\subsection{Conclusion and Recommendations Conclusion}

The main aim of this study is to assess the impact of Promotion on Profitability of an Organization. The need for an organization to properly coordinate its promotion strategies to achieve a clear, consistent and competitive message about itself and its product has become issue of concern to every result driven firm. It is worthy of note that many companies still do not understand fully the advantages of promotional mix tools in achieving their marketing objectives. This practice persists despite growing sophistication of consumers, dynamic nature of the market, growing competition in most industrial sectors and the need for efficient allocation of promotion budgets. Successful promotion relies on sound management decisions regarding the coordination and combination of options called promotional mix. These options include advertising, sales promotion, personal selling and public relations. A Careful comparison of the findings from this research shows some fundamental issues which will help the organizations to properly integrate promotion in their budgets to achieve their marketing objectives. The findings from secondary data analysis indicated that profit is slightly influenced by the variables of Sales Income even though Cost of Promotion largely influenced Sales Income. The usage of promotion will definitely increase impact, make ideas more effective and increase profit.

On the other hand, the findings from primary data analysis indicate that, advertising boost the company's image thereby leading to high profitability, sales promotion helps organizations to maintain long term customer relationships, personal selling leads to increase in sales volume and profitability in the company. This is achieved through clear, consistent and competitive messages across to target audiences. Proper implementation of public relation will help an organization to reduce its cost of promotion, and it also helps in improving the company's ability to reach the right customers with the right message, at the right time and in the right place.

Given the findings from both secondary data (see appendix five) and primary data analysis, it has been found that promotion is an important tool that helps companies to increase their profitability. The failure of some of the variables of promotions such as advertising and personal selling to produce significant impact on profitability as contained in the results of hypotheses testing may be due to the failure of the Nigeria Bottling Company Plc to give much attention to improve on such variables during the study period. The findings also revealed that, Profit is slightly influence by the variables of Sales Income even though Cost of Promotion largely influenced Sales Income.

\section{Recommendations}

1. Since a negative relationship exists between careful comparison of the findings from this research shows some fundamental issues which will help organizations to properly integrate promotion in their budgets to Cost of Promotion and Profitability as shown in the result of secondary data (4.1.3 Table 4), management should adopt policy that will reduce the Cost of Promotion. achieve their marketing objectives.

2. Ogoja depot (D3i ) had the least contribution findings from secondary data analysis indicated that profit is slightly influenced by the variables of Sales Income even though Cost of Promotion largely influenced Sales Income. The usage of promotion will to profitability as shown in secondary data of Table 5 analysis, management of the depot should ensure that all performance variables are strengthened to ensure profitability.

3. Management should help improve factors that lead to effective advertising and personal selling so that it will positively impact on profitability.

4. There is need for organizations to increasingly integrate effective promotion in their activities. Identifying the need for promotion, where and to whom it is targeted is necessary.

5. Companies need to properly integrate their promotion tools like, Advertising, Sales Promotion, Personal Selling and Public Relation with one another and pay serious attention to these tools in order to ensure clarity of messages, consistency, credibility and a highly competitive message across to target audience.

6. Improved promotion should involve proactively seeking to be collaborative in communications, jointly adopting and applying information technology, sharing research and developing trust and communications. Hence, when a firm has many subsidiaries, there is need for better coordination of promotion messages so that, the tools of promotion 
voice out same and consistent message to target audience in other to attract patronage and improve their profitability.

\section{References}

[1].Adekoya, E. C. (2011). Introduction to Research Methodology, ( $1^{\text {st }}$ edn.) Africana Feb Publishers Ltd, pp. 69- 72.

[2].Ailawadi, K. \& Neslin, S. (1998). The Effect of Promotion on Consumption: Buying More and Consuming it Faster. Journal of Marketing Research, 390-398. http://dx.doi.org/10.2307/3152036. Retrieved on 19/1/2014.

[3].Alabar, T. (2007). Basic Marketing, Principles and Practice. Makurdi: Aboki Publishers.

[4].Aren, J. (2009) "Assessing the Impact of a Very Successful Price Promotion on Brand Category Competitor Sale", Journal of Product and Brand Management, 13(5):3-14.

[5].Awe, A., Sholotan, S. and Asaolu, A. (2010). Consumer goods businesses to do well in Nigeria. Feature Article: Nigeria Business Stories.

[6].Aworemi, B. Abejide, D. L, Kevin, P. H and Collins, W. K. (2008). Public Relations Strategies and Tactics. (2 ${ }^{\text {nd }}$ edn.), New York: Harper Collins Publishers, pp. 80-96

[7].Bamiduro, J.A (2001). “An Analysis of Sales Promotion on Sales Volume in the Beverage Industry: The case Study Nigeria Bottling Company Plc.” J. Intellect. Scent and Cult. Interest. 10 (1):11- 19.

[8].Banabo, E. and Koroye B.H. (2011). "Sales Promotion Strategies of Financial Institutions in Bayelsa State". Asian J. Bus. Manage. 3(3): 203- 209.

[9].Belch, G. E. and Belch, M. A. (2007). Introduction to Advertising and Promotion: An Integrated Marketing Communication Perspective. 3th edition. Homewood: IL: Richard D. Irwin.

[10]. Belch, G. E. and Belch, M. A. (2009). Advertising and promotion: An Integrated Marketing Communication Perspective. Eight editions. McGraw-Hill. Irwin.

[11]. Bitta, B. A. (2002). The Placement and Organization of Public Relations Function. (2 ${ }^{\text {nd }}$ edn.) Butterworths. Blattberg, R. B., Briesch, R. and Fox, E.J. (1995). How Promotions Work. Marketing Science. 14(3), 122132.

[12]. Boddewyn \& Leardi (1989). General Prospects and Customers with Promotion Strategy. Retrieved from www.mgthelp.com 20/1/2014.

[13]. Chandy, D., Rajesh, C. Gerard, G, Tellis, T., Maclnnis, S. \& Thaivanich, L. (2001) "What to say when, Advertising appeal in Evolving Markets” Journal of marketing Research 34, 4 (November).

[14]. Dang, P., Koshy, A., \& Sharma, D. (2005). An Empirical Analysis of Different Types of Consumers Promotions in India Market. Asian Journal of Marketing, 104-122.

[15]. Dekimpe, M. G., Hanssens, D. M., \& Risso, J. S. (1999). Long run effects of price promotion in scanner markets. Journal of econometrics, 89, 269- 291. http://dx.doi.org/10.1016/S0304- 4076(98)00064-5. Retrieved on 1/3/2014.

[16]. Economic Times, (June 15, 2003). Sector Insight: Bottled Water Beyond the Functional Marketing. Retrieved 18 August 2004 from Brand Republic at http//www.brandrepublic.co.uk/news/newsArticle

[17]. Fisher, F. (1932). Foundation of Behavioural Research. (4 ${ }^{\text {th }}$ edn.), Edinburgh: Gate Pearson Education Ltd, pp: 46-65.

[18]. Hunt, Z. (2002). The Dynamic Effect of Discounting on Sales: Empirical Analysis and Normative Pricing Implications. Marketing Science, 18, 3,317-332. http://dx.doi.org/10.1287/mksc.18.3. 317. Retrieved on 1/3/2014.

[19]. Israel, G. D. (2013). Determining sample Size. A Publication of Department of Agricultural Education and Communication, Institute of Food and Agricultural Sciences (IFAS), University of Florida, Gaines Ville. Retrieved from http://edis.ifas.ufl.edu/pd006 on May 4, 2014.

[20]. Jefkins, F. (1990), Advertising. 3 Edition. London. Pitman Publishing Company.

[21]. Kamel, W., Carl, J. and Sunil, S. (1999).

[22]. Advertising Principles and Practice (4 edn). New Jersey: Prentice-Hall, pp: 68-71.

[23]. Karim, J. (2005) Towards a new definition of Integrated Marketing Communications - IMC, International Journal of Advertising, 24(1):7-14.

[24]. Kitchen, P.J., Brignell, J., Li, T. and Jones, G.S. (2004). The Emergence of IMC: A Theoretical Perspective, Journal of Advertising Research, pp.19-30. (The promotional process Model - adopted from Duncan, 2002).

[25]. Kokemuller, E. (2004). Monitoring Marketing and Communication Performance. www.penetrace.com. Retrieved on $1 / 3 / 2014$.

[26]. Kotler, P. (2003). Marketing Management. Analysis, Planning, Implementing and Control: $8^{\text {th }}$ edition. Prentice Hall.

[27]. Kotler, P. (2004). Marketing Management. (11th ed.), New Delhi, India: Prentice Hall International Edition.

[28]. Kotler, P. and Armstrong G., (2006). Principle of Marketing; $11^{\text {th }}$ Edition New Jersey.

[29]. Luca, B. (1999). Analysis of the Relationship Between Advertising, Concentration and Profitability in the U.S Manufacturing Industry. University of Brescia Italy.

[30]. Maddala, H. and Wu, J. (1999). Marketing Communication: Thinking outside the Box and Moving Beyond Promotion Mix. Asian Journal of Technology \& Management Research 1(2):34-39.

[31]. Mahmud, P. Alma-hirah, K., Said, W. \& Freihat, M. (2014). Perceptions of integrated marketing communications among marketers and ad agency executives in New Zealand. International Journal of Advertising, 18(1):98-109.

[32]. Makale, R. (2004). Manufacturer Trade Deals and Retail Price promotions, Journal of Marketing and Research, 
27(4):28-34.

[33]. McNamara, D. S. (2001). Reading both high and low coherence texts: Effects of text sequence and prior knowledge. Canadian Journal of Experimental Psychology, 55, 51-62.

[34]. Mehir, B., Bipasha, O. and Kamel, J. (2008). The Impact of Sales Promotion on Organization Effectiveness in Nigerian Manufacturing Industry. Universal Journal of Marketing and Business Research (ISSN: 2315- 5000) Vol. 1(4) pp. 123-131, October, 2012

[35]. Nagar, R.M. (2009). Assessment of Effectiveness of Marketing Communication Mix Elements in Ethiopian Service Sector, Journal of Business Management, 2(3):59-64.

[36]. NBC plc. (2012). Nigerian Bottling Company. Retrieved from Coca-cola: http://www.nbcplccareers.com/about us.php. Retrieved on 12/4/2014.

[37]. Obi, M. (2002). Performance Auditing Of Integrated Marketing Communication (IMC) Actions And Outcomes, Journal of Advertising, 34(4):41-54.

[38]. Odunlami I.B, and Ogunsiji, A. (2011). Effect of sales promotion as a tool on organizationa performance. J. Emerg. Trends in Econ. And manage. Sci. (JETEMS). 2(1):9-13.

[39]. Okoli, P. (2011). Consequences of perceiving oneself as responsible for obtaining a discount: evidence for smartshopper feelings, Journal of Consumer Psychology, 7(4):371-382.

[40]. Okwo, D. E. and Ugwunta, P. J. (2010), Integrated Marketing communications in Nigeria. Journal of Advertising Research, 37(5):7-18.

[41]. Ozor, S. J. (2000) The State of IMC Research and Application. Journal of Advertising and Research. 40(5):22-43

[42]. Pauwels, K., Hanssens, D. M., and Siddarth,

[43]. S. (2002). The Long Term Effects of Price Promotions on Category Incidence, Brand Choice and Purchase Quantity Journal. 3(5):22- 26.

[44]. Preko, A. (2012): The Effect of Sales Promotion on TV Advertising Revenue: (A Case Study of TV Africa, Ghana). J. Emerg. Trends in Econ. and Manage. Sci. (JETEMS) 3 (2): 141-146

[45]. Rizvi, S.M, \& Malik, G.M (2011). Effective Public Relations. (2 ${ }^{\text {nd }}$ edn.), Englewood Cliffs, New Jersey: Prentice Hall.

[46]. Rotimosho, A. (2003). Practice of Marketing. 1st Edition. Lagos: Global Annuals.

[47]. Shimp, T. (2003). "Countries and Their Products; A Cognitive Structure Perspective," Journal of the Academy of Marketing Science, vol.21:4, pp. 323-330.

[48]. Shimp, T. (2000). Advertising, Promotion, and Supplemented Aspects of Integrated Marketing Communication. $5^{\text {th }}$ Edition, New York: Dryden Press.

[49]. Shira, S. R. (2003). Marketing. 1st Edition, Delhi: A. H Wheeler and C. Ltd.

[50]. Stanton, W., Etzel, M.J., and Walker, B.J.(2001). Marketing. $12^{\text {th }}$ Edition. New York: McGraw-Hill Inc.

[51]. Sweney, M. (2004). IMC Using Advertising and Promotion to build brand (International Edition) New York: The McGraw-Hill Companies, Inc.

[52]. Syeda, N. Z., Sadia, M., Lahre, P. \& Syeda, F. B. (2012). "Short Term and Long Term Impact of Sales Promotion on Organizations' Profitability: “A Comparative Study between Convenience and Shopping Goods”. Int. J. Bus. And Manage. 7(5): 247- 255.

[53]. Tahir, H. (2007). Sales Promotion Dissertation. Homewood: IL: Richard D. Irwin.

[54]. Wright R. (2000) Advertising; First Edition, Harlow Pearson Education Ltd. Yin,

[55]. R. K. (1994) "Case Study Research: Design and Methods”. Thousand Oaks, Sage Publications.

[56]. Wise-GEEK.(2003). Understanding Profitability. www.extension.iastate.edu/agdm/wh ol. Retrieved 22/6/2014. 